\title{
HOXA11 wt Allele
}

National Cancer Institute

\section{Source}

National Cancer Institute. HOXA11 wt Allele. NCI Thesaurus. Code C97569.

Human HOXA11 wild-type allele is located in the vicinity of 7p15.2 and is approximately 4 kb in length. This allele, which encodes homeobox protein Hox-A11, plays a role in transcriptional regulation. Mutation of the gene is associated with radioulnar synostosis with amegakaryocytic thrombocytopenia. Two chromosomal aberrations inv(7)(p15q34) and $t(7 ; 7)(p 15 ; q 34)$ of this gene and the TCRB gene locus lead to ectopic expression of the HOXA11 gene and are associated with T-cell acute lymphoblastic leukemia. A chromosomal translocation $\mathrm{t}(7 ; 11)(\mathrm{p} 15 ; \mathrm{p} 15)$ of this gene and the NUP98 gene might be associated with chronic myelogenous leukemia. 